\title{
Stratégiai szemléletváltás a Marfan-szindrómás betegeken végzett aortagyök-rekonstrukciókban
}

\author{
Pólos Miklós dr. ${ }^{1,2}$ - Stengl Roland dr. ${ }^{1,2}$ - Şulea Cristina-Maria ${ }^{4}$ \\ Benke Kálmán dr. ${ }^{1,2}$. Bartha Elektra dr., ${ }^{1,2}$. Ágg Bence dr. ${ }^{1,2,3}$ \\ Koppányi Ádám dr. ${ }^{1}$ - Hartyánszky István dr. ${ }^{1}$ \\ Székely Andrea dr. ${ }^{5}$. Németh Endre dr. ${ }^{5}$. Kovács Attila dr. ${ }^{1}$ \\ Merkely Béla dr. ${ }^{1}$. Szabolcs Zoltán dr. ${ }^{1,2}$
${ }^{1}$ Semmelweis Egyetem, Általános Orvostudományi Kar, Városmajori Szív- és Érgyógyászati Klinika, Budapest
${ }^{2}$ Magyar Marfan Alapítvány, Budapest
${ }^{3}$ Semmelweis Egyetem, Általános Orvostudományi Kar, Farmakológiai és Farmakoterápiás Intézet, Budapest ${ }^{4}$ Marosvásárhelyi „George Emil Palade” Orvosi, Gyógyszerészeti, Tudomány és Technológiai Egyetem, Marosvásárhely, Románia \\ ${ }^{5}$ Semmelweis Egyetem, Általános Orvostudományi Kar, Aneszteziológiai és Intenzív Terápiás Klinika, Budapest
}

Bevezetés: A Marfan-szindróma autoszomális domináns módon öröklődő, szisztémás kötőszöveti betegség. A hosszú távú túlélés szempontjából fontos a nagyérkatasztrófák megelőzése. Szívsebészeti szempontból a legfontosabb elváltozás az aortagyök tágulata. Aortagyök-rekonstrukciós beavatkozásaink Bentall-DeBono-, David I. és módosított Yacoub-mútétek, melyek mind preventív jelleggel, mind dissectio esetén jó eredménnyel végezhetők.

Célkitüzés: A marfanos betegeknél eltérő technikával végzett aortagyök-rekonstrukciós mütéteink összehasonlítása. Módszer: A Semmelweis Egyetem Városmajori Szív- és Érgyógyászati Klinikáján 1993 és 2020 között Marfan-szindrómásoknál elvégzett Bentall-DeBono-, David I. és módosított Yacoub-féle aortagyök-rekonstrukciókat elemeztük. A műtét szerinti csoportok életkora a beavatkozás idején 29,69 (21,98-41,25) év, 29,15 11 , 99 év és 35,29 $\pm 14,14$ év volt, a fenti sorrendben. Az adatok forrásául a Magyar Marfan Regiszter és az Aortagyök-rekonstrukciós Regiszter szolgált.

Eredmények: Az utánkövetési idő $132 \pm 81,04$ hónap volt a Bentall-, $76 \pm 27,77$ hónap a David-, valamint 4,5 (0,75-11,75) hónap a Yacoub-mútét esetén. A David- és a Yacoub-beavatkozások gyakrabban voltak profilaktikusak, mint a Bentall-operációk $(\mathrm{p}=0,0153 ; \mathrm{p}=0,0085)$. A Bentall-mütéteknél ritkább volt a primer mútét esetleges későbbi elégtelenségéből fakadó reoperáció, mint a David-operációknál $(\mathrm{p}<0,001)$. David-beavatkozásnál a Bentallmútéthez képest hosszabb volt a cardiopulmonaris bypass $(\mathrm{p}=0,0013)$ és az aortalefogás ideje $(\mathrm{p}=0,0048)$, valamint David- és Yacoub-mútét esetén gyakrabban lépett fel korai posztoperatív szövődmény, mint Bentall-operációnál ( $\mathrm{p}=0,0005 ; \mathrm{p}=0,0037)$. A késői szövődmények és a túlélés tekintetében a csoportok nem különböztek.

Következtetés: Marfan-szindrómában a leggyakrabban halált okozó szövődmény az akut aortaruptura, illetve akut aortadissectio. Eredményeink alapján mindhárom profilaktikus aortagyök-rekonstrukciós mútéti típus jól reprodukálható és jó eredménnyel végezhető Marfan-szindrómában.

Orv Hetil. 2021; 162(18): 696-704.

Kulcsszavak: aortagyök-rekonstrukció, Bentall-műtét, David-mútét, Yacoub-műtét, Marfan-szindróma

\section{Changing strategies in aortic root reconstruction in Marfan syndrome}

Introduction: Marfan syndrome is an autosomal dominant, systemic connective tissue disorder. Preventing vascular complications is essential for long-term survival. Aortic dilation is the main cardiac surgical manifestation. BentallDeBono, David I and modified Yacoub aortic root reconstructions treat and prevent aortic dissections with great outcomes.

Objective: Comparing results of aortic root reconstructions in Marfan syndrome.

Method: We analysed the data of Bentall-DeBono, David I and modified Yacoub operations performed in Marfan syndrome at the Heart and Vascular Center, Semmelweis University between 1993 and 2020. Ages of surgical groups 
at the time of operation were $29.69(21.98-41.25)$ years, $29.15 \pm 11.99$ years and $35.29 \pm 14.14$ years, respectively. Data were obtained from the Hungarian Marfan Register and the Aortic Root Reconstruction Register.

Results: Follow-up time was $132 \pm 81.04$ months for Bentall, $76 \pm 27.77$ months for David and $4.5(0.75-11.75)$ months for Yacoub groups. David and Yacoub operations were prophylactic more frequently than Bentall ones $(\mathrm{p}=$ $0.0153 ; p=0.0085)$. Freedom from reoperation after primary surgery insufficiency was more common for Bentall than for David procedure $(\mathrm{p}<0.001)$. Compared to Bentall, David surgeries required longer cardiopulmonary bypass $(\mathrm{p}=0.0013)$ and aortic cross clamp time $(\mathrm{p}=0.0048)$, more early postoperative complications occurred after David and Yacoub, than after Bentall operations $(\mathrm{p}=0.0005 ; \mathrm{p}=0.0037)$. Late complications and survival did not differ among the groups.

Conclusion: In Marfan syndrome, acute aortic rupture and dissection are the main contributors to mortality. Based on our results, the prophylactic aortic root reconstructions are reproducible and can be performed with great outcomes.

Keywords: aortic root reconstruction, Bentall procedure, David procedure, Yacoub procedure, Marfan syndrome

Pólos M, Stengl R, Şulea C-M, Benke K, Bartha E, Ágg B, Koppányi Á, Hartyánszky I, Székely A, Németh E, Kovács A, Merkely B, Szabolcs Z. [Changing strategies in aortic root reconstruction in Marfan syndrome]. Orv Hetil. 2021; 162(18): 696-704.

(Beérkezett: 2020. október 11.; elfogadva: 2020. november 24.)

\begin{abstract}
Rövidítések
$\mathrm{ANOVA}=($ analysis of variance $)$ varianciaanalízis; $\mathrm{BMI}=($ body mass index) testtömegindex; $\mathrm{CNV}=($ copy number variation $)$ kópiaszám-eltérés; $\mathrm{CPB}=$ cardiopulmonalis bypass; $\mathrm{DHCA}=$ (deep hypothermic circulatory arrest) mély hypothermiás keringésmegállítás; $\mathrm{EF}=$ ejekciós frakció; $\mathrm{FBNl}=$ fibrillin- 1 ; TGF $=$ (transforming growth factor $)$ transzformáló növekedési faktor; TRR = (total root replacement) teljes aortagyök-csere; VSRR = (valve sparing root replacement) billentyümegőrzó aortagyökcsere
\end{abstract}

A Marfan-szindróma autoszomális domináns módon öröklődő, szisztémás kötőszöveti betegség, becsült prevalenciája $1: 5000-1: 10000[1]$. A legsúlyosabb manifesztációk a cardiovascularis szervrendszert érintik. Idetartozik a magas halálozással járó aortadissectio, valamint az aortagyök fenyegető tágulata [2-4] az aortabillentyú következményes diszfunkciójával, a mitralis, valamint a tricuspidalis billentyü prolapsusa [5]. A cardiovascularis érintettségek közé tartozik ezenfelül az artériák fokozott tortuositasa, azaz kanyargóssága is, amely az egyéb azonosított tényezők mellett $[6,7]$ a súlyosabb aortaérintettség egyik prediktora [8]. A szindróma továbbá jellegzetes szem- és musculoskeletalis tünetekkel jár. Az utóbbiak közül kiemelendő a hosszú csöves csontok túlnövekedése, a mellkas deformitásai (pectus carinatum és pectus excavatum), a megnövekedett karfesztávolságtestmagasság arány, a csökkent felső szegment-alsó szegment arány, az arachnodactylia (pókujjúság), a scoliosis, a csukló- és hüvelykujjtünet, a pes planus, a hipermobilis ízületek, valamint a craniofacialis érintettség. Jellemző szemtünet a lencse diszlokációját jelentő ectopia lentis, amely a betegek $60 \%$-ában megtalálható, de megjelenése nem csupán a Marfan-szindrómára korlátozódik [5]. A leggyakoribb szemtünet a myopia [1].
Az esetek jelentős részében a betegség hátterében a fibrillin-1 fehérjét kódoló FBNl-gén mutációja áll [9]. A kóroki variáció a Marfan-szindrómás betegek több mint 90\%-ában kimutatható, ami a kópiaszám-eltérések (CNV-k) célzott keresésével tovább növelhető [10]. A fehérje az extracelluláris mátrix fontos alkotórésze, az elasztikus rostok kialakításában kulcsszerepet játszik, a TGFß inaktív formában tartásával pedig szabályozó funkcióval is bír. A fibrillin-1 mennyiségének csökkenése vagy szerkezetének károsodása tehát közvetlenül és közvetett módon felelős a szindróma tüneteinek kialakulásáért [11].

A Marfan-szindróma diagnózisának alapját az 1996. évi Gent-nozológiát felváltó, 2010. évi átdolgozott Gent-nozológia adja, amelyben nagy hangsúlyt kap az aortagyök aneurysmája/dissectiója, a genetikai variáció és az ectopia lentis megléte [12].

Az akut A-típusú aortadissectio magas mortalitású állapot [13], amely alacsony kockázattal járó profilaktikus mútéttel [14] megelőzhető. Az irányelveknek megfelelően a beavatkozás alapját az aorta átmérője képezi. Marfan-szindrómában a beavatkozás indikált, amennyiben a felszálló aorta átméróje $\geq 50 \mathrm{~mm}$, illetve a következő rizikótényezők valamelyikének jelenléte esetén ez az érték 45 mm-re csökken: aortadissectio családi előfordulása, súlyos aorta- vagy mitralis regurgitatio, illetve az aorta átmérőjének növekedési üteme $\geq 3 \mathrm{~mm} /$ év. Várandósság tervezése esetén $40 \mathrm{~mm}$ felett indikált a profilaktikus aortagyök-rekonstrukció $[15,16]$.

$\mathrm{Az}$ aortagyök dilatatiója és dissectiója esetén szóba jövő aortagyök-rekonstrukciós mútéteknek két alapvető típusát különböztetjük meg. Az egyik a teljes aortagyökcsere (total root replacement - TRR), azaz az arany standardnak számító Bentall-DeBono-operáció [17], amely a bevezetése óta számos módosításon ment keresztül 
[18, 19]. A Bentall-mútétek lényege a tágult aortagyök, a felszálló aorta és az aortabillentyú cseréje, ami az esetek többségében - lévén fiatal betegeket érintő betegség mechanikus billentyưvel ellátott conduittal történik. A mechanikus múbillentyú alkalmazásának előnye annak időtállósága, míg jelentős hátránya, hogy élethosszig tartó antikoaguláns kezelést igényel a mechanikus múbillentyú jelentette fokozott thromboemboliás kockázat miatt [20]. A tartós antikoagulációval járó szövődmények és nehézségek kiküszöbölésére fejlesztették ki a billentyű megtartásával járó aortagyök-rekonstrukciós eljárásokat [21]. Ezen billentyümegőrző aortagyökcserék (valve sparing root replacement - VSRR) egyik típusa a billentyüreimplantációval járó David-mütét [22], míg a másik variáció a Valsalva-sinusok remodellációját alkalmazó Yacoub-beavatkozás [23]. A VSRR-ek esetében felmerül, hogy ezen mútétek technikailag komplikáltabbak, és egyesek a natív billentyű időtállóságát is megkérdőjelezik [24]. A billentyưmegtartó mútétek eredményességét azonban számos szerző támasztotta alá [25-30]. Ezt követve Klinikánkon is módosítottunk korábbi gyakorlatunkon, és megfelelően kiválasztott betegcsoportnál bevezettük a billentyümegtartó aortagyökrekonstrukciós mütéteket. Ehhez kapcsolódik, hogy Klinikánkon majd két évtizede múködik Marfan-ambulancia a 2002-ben alapított Magyar Marfan Alapítvány gondozásában. Az Ambulancia célja a Marfan-szindrómás betegek szürése és követése országos, de lassan már Kárpát-medencei jelleggel is, kiemelten fókuszálva a multidiszciplináris megközelítésre és a Marfan-szindrómás betegekre jellemző pszichoszociális és pszichológiai tényezők figyelembevételére [31, 32]. Célul tüztük ki az érkatasztrófák megelőzését a betegek rendszeres képalkotó vizsgálattal történő követésével és a profilaktikus mütétek időbeli elvégzésével.

\section{Módszer}

Vizsgálatunkban retrospektív módon elemeztük a Semmelweis Egyetem Városmajori Szív- és Érgyógyászati Klinikáján 1993 és 2020 között marfanos betegeken végrehajtott aortagyök-rekonstrukciós mútéteket. Az elvégzett mütéti típusok Bentall-DeBono-, David I. és módosított Yacoub-beavatkozások voltak. A Marfanszindróma diagnózisának alapját 2010 előtt az érvényben lévő Berlin- és Gent-nozológia, az azt követő időszakban az átdolgozott Gent-nozológia képezte [12].

Az elektív és sürgős jellegű aortagyök-rekonstrukciókat elemeztük, amelyekből összesen 89-et végeztünk; ebből 62 Bentall-DeBono-, 13 David I. és 14 módosított Yacoub-mútétet (Schäfers szerinti annulusstabilizálással) [33] hajtottunk végre Marfan-szindrómás betegeinknél. A billentyümegtartó mútétek esetében minden alkalommal végeztünk cuspisplasztikát (plicatio), amenynyiben a cuspis effektív magassága nem érte el a 9 mm-t. Minden billentyümegtartó mútét esetében történt intra- operatív echokardiográfiás vizsgálat, a plasztika eredményességének ellenőrzésére. A beavatkozások idején az életkor 29,69 (21,98-41,25) év, 29,15 \pm 11,99 év és $35,29 \pm 14,14$ év volt. Vizsgálatunk során ezeket a csoportokat hasonlítottuk össze egymással.

Elsődleges végpontokként a primer mütét elégtelensége következtében szülkségessé váló reoperációt, valamint a halálozást vizsgáltuk.

Az adatok forrása az anamnesztikus, klinikai és echokardiográfiás jellemzőket is tartalmazó Aortagyökrekonstrukciós Regiszter, valamint a Magyar Marfan Regiszter [34]. Az utánkövetés végének a Magyar Marfan Regiszterben az adott beteg esetén elvégzett utolsó módosítás dátumát vagy a halálozás időpontját tekintettük. Az utánkövetési idő $132 \pm 81,04$ hónap volt a Bentall-DeBono-, $76 \pm 27,77$ hónap a David I., valamint 4,5 (0,75-11,75) hónap a módosított Yacoub-mütéten átesettek körében.

\section{Statisztika}

A normalitás vizsgálatára Shapiro-Wilk-féle normalitástesztet alkalmaztunk. A normalitásuktól függően a folytonos változókat normáleloszlás esetén átlag és standard deviáció, míg nem normáleloszlás során medián és interkvartilis formátumban tüntettük fel.

A csoportok összehasonlítására folytonos változók esetén normáleloszláskor egyutas ANOVA-t használtunk Tukey-féle post-hoc teszttel, míg nem normáleloszlás esetén Kruskal-Wallis-próbát alkalmaztunk Dunn-féle post-hoc teszttel, kategorikus változók esetén pedig Fisher-egzakt tesztet használtunk. A 3 csoport túlélését és reoperációtól való mentességét Kaplan-Meier-görbéken ábrázoltuk, a csoportok összehasonlításához logrank tesztet használtunk.

$\mathrm{Az}$ eredményeket Bonferroni-korrekciót alkalmazva p<0,017 értéknél tekintettük szignifikánsnak.

\section{Eredmények}

\section{Bentall-DeBono-mütét}

A Bentall-DeBono-mútéten átesett betegeink között 41 (66\%) férfi és 21 (34\%) nő volt. Hypertonia 35\%-ban $(22 / 62)$ fordult elő, ez volt a leggyakoribb komorbiditás. A felszálló aorta átmérője 56 (50-65) mm-nek adódott, míg az aortaregurgitatio foka $3(1,75-4)$ volt. A mútét előtti ejekciós frakció (EF) 60 (58-64,75) \%, a mútét utáni pedig $60(51,5-65) \%$ volt.

Profilaktikus aortagyök-rekonstrukció 24 (39\%) esetben történt, a többi esetben a műtéti indikáció határát meghaladó méretû aortoannulectasia és sinus Valsalvae tágulat képezte a mútét indikációját.

$56(90 \%)$ mechanikus és $6(10 \%)$ biológiai conduit billentyü került beültetésre, ezek medián átmérője 27 (25-27) mm volt. 
Kísérő beavatkozásként 9 mitralisbillentyü-mütétet, 2 coronariabypass-mútétet, 5 teljes és 1 parciális aortaívcserét és 1 pacemaker-implantációt végeztünk.

A mútéti idő 250 (210-300) percnek, míg az aortalefogás ideje 112,5 (100-146,3) percnek bizonyult. 14 (23\%) esetben történt mély hypothermiás keringésmegállítás (DHCA).

Intraoperatív szövődmény 9 (15\%, vérzéses szövődmény, illetve intraoperatív pacemakerigény), korai posztoperatív - első 30 nap (tamponád, illetve posztoperatív pitvarfibrilláció) - szövődmény 5 (8\%), míg késői posztoperatív - 1 éven belüli (ritmuszavar, thromboemboliás esemény) - szövődmény 2 (3\%) esetben fordult elő.

2 esetben volt szükség reoperációra a primer mütét elégtelensége kapcsán (3\%), míg 15 (24\%) operált beteg hunyt el az utánkövetési idő alatt.

\section{David I. mütét}

A David I. csoport 8 férfit (61\%) és 5 nőt (39\%) tartalmazott. Komorbiditásként 1 (7,7\%) esetben hypertonia, további $1(7,7 \%)$ esetben pedig hyperlipidaemia volt jelen. A felszálló aorta átméróje 49,85 \pm 7,022 mm, az aortaregurgitatio foka pedig 2 (0-2) volt. Az echokardi- ográfiával mért, mütét előtti EF $62,31 \pm 3,521 \%$-nak bizonyult, míg a mútét után 60 (55-60) \%-ra módosult.

Profilaktikus beavatkozás $10(77 \%)$ alkalommal történt. A mütéti idő $312,2 \pm 55,26$ perc volt, míg az aortalefogás ideje 153,6 $\pm 23,28$ percnek adódott. 1 esetben $(7,7 \%)$ alkalmaztunk DHCA-t.

Intraoperatív szövődményként 1 esetben $(7,7 \%)$ vérzés, $3(23 \%)$ esetben arrhythmia következett be. Korai posztoperatív szövődmény pedig 7 (54\%) betegnél lépett fel, ezek közül 2 vérzés, 1 pericardialis tamponád és 4 arrhythmia (posztoperatív pitvarfibrilláció) volt. Késői posztoperatív szövődmény nem alakult ki.

Az utánkövetés során 4 (31\%) beteg szorult reoperációra $(52,25,18,12$ hónappal a mútét után), mindegyik esetben a billentyưmegőrző mütétet követően kialakuló, IV-es fokú aortaregurgitatio (3 esetben prolapsus, I esetben késői endocarditis) volt az indikáció. A követés során haláleset nem fordult elö ebben a csoportban.

\section{A módositott Yacoub-mütét}

Az aortagyök-remodellációs mütéten átesettek között 10 férfi (71\%) és 4 nő (29\%) volt. Hypertonia 2 (14,3\%), hyperlipidaemia pedig $1(7,1 \%)$ betegnél fordult elő. A felszálló aorta átmérője 49,21 \pm 4,611 mm-nek bizo-

1. táblázat | A három mútéti típus paramétereinek összehasonlítása

\begin{tabular}{|c|c|c|c|c|c|c|}
\hline & \multirow{2}{*}{$\begin{array}{l}\text { 1. Bentall-DeBono- } \\
\text { mútét }\end{array}$} & \multirow[t]{2}{*}{ 2. David I. mútét } & \multirow{2}{*}{$\begin{array}{l}\text { 3. Módosított } \\
\text { Yacoub-mútét }\end{array}$} & \multicolumn{3}{|c|}{$\mathrm{p}$} \\
\hline & & & & 1 vs. 2 & 1 vs. 3 & 2 vs. 3 \\
\hline Betegszám & 62 & 13 & 14 & & & \\
\hline \multicolumn{7}{|c|}{ Klinikai paraméterek } \\
\hline Életkor ${ }^{2}$ & $29,69(21,98-41,25)$ & $29,15 \pm 11,99$ & $35,29 \pm 14,14$ & $>0,9999$ & $>0,9999$ & 0,6308 \\
\hline Nem (férfi) ${ }^{3}$ & $41(66 \%)$ & $8(61 \%)$ & $10(71 \%)$ & 0,7574 & $>0,9999$ & 0,6946 \\
\hline $\mathrm{BMI}^{1}$ & $22,6 \pm 3,8$ & $21,57 \pm 4,75$ & $23,64 \pm 3,39$ & 0,6861 & 0,6616 & 0,3864 \\
\hline Magas vérnyomás 3 & $22(35 \%)$ & $1(7,7 \%)$ & $2(14,3 \%)$ & 0,0545 & 0,2026 & $>0,9999$ \\
\hline Koszorúér-betegség³ & $2(3 \%)$ & $0(0 \%)$ & $0(0 \%)$ & $>0,9999$ & $>0,9999$ & $>0,9999$ \\
\hline Mitralisbillentyú-mútét ${ }^{3}$ & $9(15 \%)$ & $0(0 \%)$ & $0(0 \%)$ & 0,3446 & 0,1965 & $>0,9999$ \\
\hline Aortaátmérö $(\mathrm{mm})^{2}$ & $56(50-65)$ & $49,85 \pm 7,022$ & $49,21 \pm 4,611$ & 0,0114 & 0,0066 & $>0,9999$ \\
\hline $\mathrm{Az}$ aortaregurgitatio foka ${ }^{2}$ & $3[1,75-4)$ & $2(0-2)$ & $0(0-1)$ & 0,0195 & $<0,0001$ & 0,6542 \\
\hline NYHA-stádium > $1^{3}$ & $11(18 \%)$ & $2(15 \%)$ & $4(29 \%)$ & $>0,9999$ & 0,4570 & 0,6483 \\
\hline EuroSCORE II. $(\%)^{2}$ & $2(1-6)$ & $1,691 \pm 0,5317$ & $2,357 \pm 0,8198$ & 0,8630 & $>0,9999$ & 0,7526 \\
\hline $\mathrm{CPB}$-idő$^{2}$ & $146,5(130-195,5)$ & $167,3 \pm 53,11$ & $157(145,5-205)$ & 0,0013 & 0,7533 & 0,1976 \\
\hline Mütéti idő > $5 \mathrm{~h}^{3}$ & $16(26 \%)$ & $7(54 \%)$ & $5(36 \%)$ & 0,0940 & 0,5137 & 0,4495 \\
\hline $\begin{array}{l}\text { Mély hypothermiás kirekesztés } \\
\text { alkalmazása }{ }^{3}\end{array}$ & $14(23 \%)$ & $\mathrm{l}(7,7 \%)$ & $4(28,6 \%)$ & 0,4448 & 0,7297 & 0,3259 \\
\hline Az aortalefogás ideje ${ }^{2}$ & $112,5(100-146,3)$ & $153,6 \pm 23,28$ & $132,8 \pm 24,49$ & 0,0048 & 0,4214 & 0,5714 \\
\hline Korai szövődmény ${ }^{3}$ & $5(8 \%)$ & $7(54 \%)$ & $6(43 \%)$ & 0,0005 & 0,0037 & 0,7064 \\
\hline Késői szövődmény ${ }^{3}$ & $2(3 \%)$ & 0 & 0 & $>0,9999$ & $>0,9999$ & $>0,9999$ \\
\hline Profilaktikus mütét ${ }^{3}$ & $24(39 \%)$ & $10(77 \%)$ & $11(79 \%)$ & 0,0153 & 0,0085 & $>0,9999$ \\
\hline
\end{tabular}

${ }^{1}$ ANOVA Tukey-féle post-hoc teszttel; ${ }^{2}$ Kruskal-Wallis-próba Dunn-féle post-hoc teszt; ${ }^{3}$ Fisher-egzakt teszt

ANOVA = varianciaanalízis; $\mathrm{BMI}=$ testtömegindex $\mathrm{CPB}=$ cardiopulmonalis bypass; NYHA = New York-i Szívbetegséggel Foglalkozó Társaság 
nyult, az aorta regurgitatiója $0(0-1)$ volt. A mütét előtti EF 59,5 \pm 4,071\% volt.

A beavatkozások közül 11 (79\%) volt profilaktikus. Kísérő beavatkozásként $2(14,3 \%)$ teljes aortaívcserét végeztünk. A mütéti idő $250(238,8-342,8)$ perc, az aortalefogási idő $132,8 \pm 24,49$ perc volt. $4(28,6 \%)$ alkalommal volt szükség DHCA-ra.

Intraoperatív szövődményként 2 esetben arrhythmia fordult elö ezen mútéti típus esetén. Korai posztoperatív szövődményként 1 betegnél vérzés, 4 (28,6\%) betegnél szívritmuszavar (posztoperatív pitvarfibrilláció), míg l esetben pericardialis tamponád alakult ki. Késői posztoperatív szövődmény nem lépett fel.

A teljes utánkövetési idő alatt az ezen módszerrel operált betegeink esetén nem volt szükség reoperációra, és nem fordult elő halálozás.

\section{A csoportok összehasonlitása}

Az 1. táblázatban foglaltuk össze a különböző elektív és sürgős mütéten áteső betegek klinikai adatait és a mütétekkel kapcsolatos információkat. Az egyszerúség kedvé- ért a továbbiakban a mütéteket Bentall, David és Yacoub néven is említjük. Az aortagyök intraoperatív képe látható az 1. ábrán.

A csoportok nemi eloszlása, mütétkori átlagéletkora, BMI-értéke és a komorbiditások tekintetében nem volt különbség a csoportok között.

A felszálló aorta átmérője szignifikánsan nagyobb volt a Bentall-csoportban, mint a David- és Yacoub-mútéten átesettek között $(\mathrm{p}=0,0114$ és $\mathrm{p}=0,0066)$. A David- és Yacoub-csoportok összevetésekor ebben a tekintetben nem volt eltérés ( $p>0,9999)$.

Az operáció előtti aortaregurgitatio foka szignifikánsan nagyobb volt a Bentall-mútéten átesőkön, mint a Yacoub-, és tendenciózusan nagyobb, mint a Davidcsoportban $(\mathrm{p}<0,0001$ és $\mathrm{p}=0,0195)$, míg az utóbbi 2 csoport összevetésekor nem mutatkozott különbség $(\mathrm{p}=0,6542)$.

A mútéti jellemzókben is adódtak különbségek a csoportok között. A cardiopulmonalis bypass (CPB) használatának ideje szignifikánsan hosszabb volt David-beavatkozás során, mint Bentall-mütétnél $(\mathrm{p}=0,0013)$. Ezzel párhuzamosan az aortalefogás ideje is szignifikán-
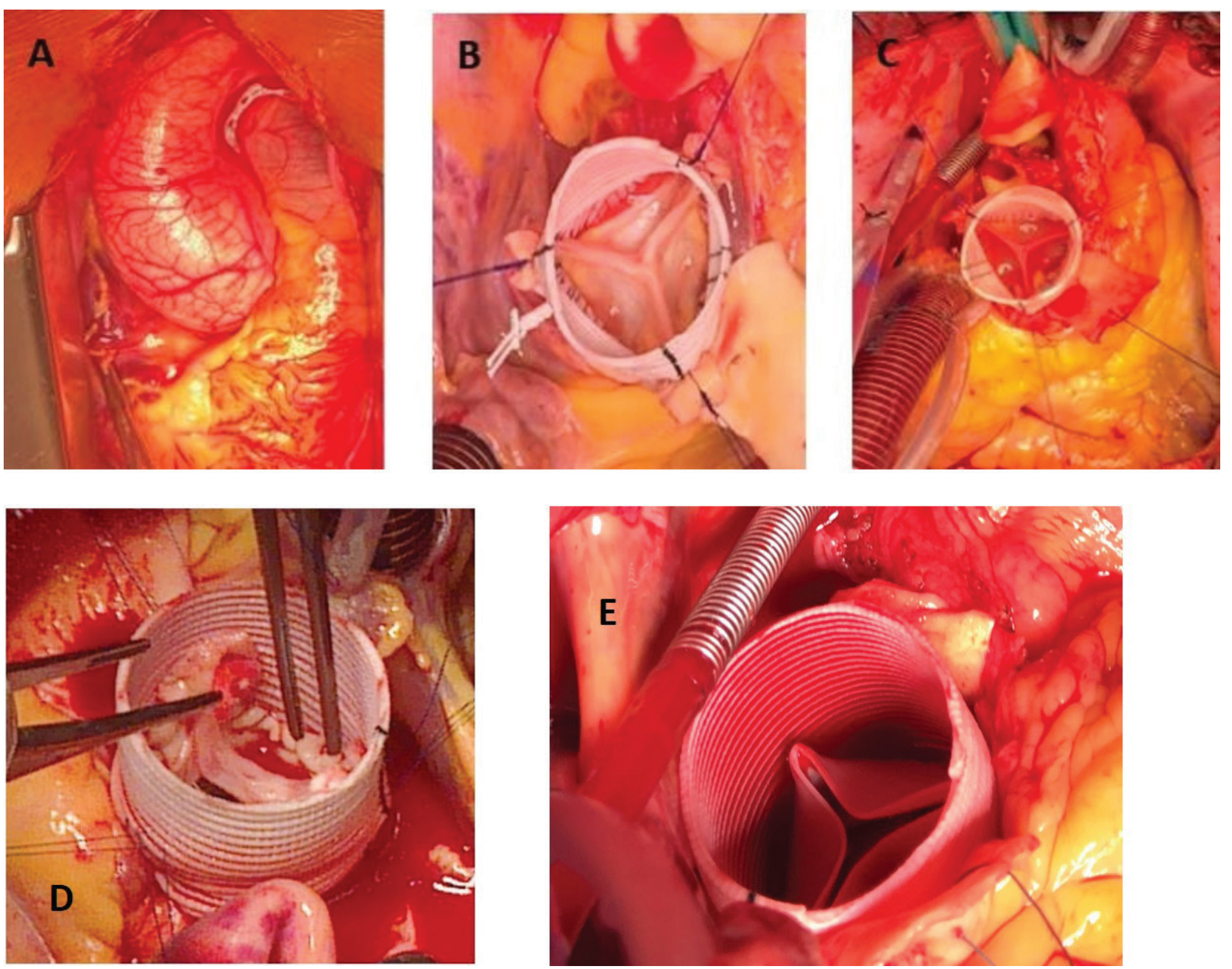

1. ábra $\quad$ Aortagyök-rekonstrukciós műtét intraoperatív képei. A) Jelentősen tágult felszálló aorta. B, C) Az aortagyök remodellációja Yacoub szerint. D) Aortagyök-reimplantáció (David-mútét). E) Bentall-mútét intraoperatív képe (biológiai billentyút tartalmazó conduit) 
2. táblázat

Szövődmények a mútéti típusok szerint

\begin{tabular}{|c|c|c|c|}
\hline & $\begin{array}{l}\text { Bentall-DeBono- } \\
\text { mútét } \\
(\mathrm{n}=62)\end{array}$ & $\begin{array}{l}\text { David I. mútét } \\
\qquad(\mathrm{n}=13)\end{array}$ & $\begin{array}{l}\text { Módosított } \\
\text { Yacoub-mútét } \\
(\mathrm{n}=14)\end{array}$ \\
\hline \multicolumn{4}{|c|}{ Intraoperatív szövődmény (\%) } \\
\hline Vérzés & 6 & 8 & 0 \\
\hline Arrhythmia & 8 & 23 & 14 \\
\hline \multicolumn{4}{|c|}{ Korai posztoperatív szövődmény (\%) } \\
\hline Vérzés & 5 & 15 & 7 \\
\hline Arrhythmia & 3 & 31 & 29 \\
\hline $\begin{array}{l}\text { Pericardialis } \\
\text { tamponád }\end{array}$ & 0 & 8 & 7 \\
\hline \multicolumn{4}{|c|}{ Késői posztoperatív szövődmény (\%) } \\
\hline Vérzés & 2 & 0 & 0 \\
\hline Arrhythmia & 2 & 0 & 0 \\
\hline
\end{tabular}

san hosszabb volt David-mútét esetén, mint Bentalloperáció kapcsán $(\mathrm{p}=0,0048)$. Az 5 óránál hosszabb mütétek előfordulása gyakoribb volt David-operációkor, mint a másik két mútét esetén, de az eltérés nem volt szignifikáns. A DHCA alkalmazásának gyakorisága tekintetében nem volt különbség a csoportok között.

David- és Yacoub-mütétek kapcsán szignifikánsan gyakrabban alakult ki korai posztoperatív szövődmény, mint Bentall-beavatkozások esetén ( $\mathrm{p}=0,0005$ és $\mathrm{p}=$ $0,0037)$. A késői szövődmények tekintetében nem volt különbség (2. táblázat).

Bentall-mútétek kapcsán szignifikánsan kisebb gyakorisággal fordult elö profilaktikus beavatkozás, mint David- és Yacoub-operációk esetén ( $\mathrm{p}=0,0153$ és $\mathrm{p}=$ $0,0085)$.

A log-rank teszt alapján a reoperációmentesség szignifikánsan gyakoribb volt Bentall-mütét esetén, mint David-beavatkozást követően $(p<0,001)$. A Bentall- és a Yacoub-, illetve a David- és a Yacoub-csoportokat összehasonlítva nem találtunk közöttük különbséget $(\mathrm{p}=0,713$ és $\mathrm{p}=0,485)$ (2. ábra). A mútéti típusok reoperációmentességének összehasonlításakor a teljes utánkövetési időszakot vettük figyelembe, amely Bentallmütét esetén 299 hónap, David-operációkor 111 hónap, míg Yacoub-beavatkozás esetén 42 hónap volt.

A túlélés tekintetében a log-rank teszt alapján nem volt különbség a csoportok között (Bentall vs. David: $\mathrm{p}=0,142$ és Bentall vs. Yacoub: $\mathrm{p}=0,386$ ) (3. ábra). A túlélést szintén a teljes utánkövetési időszakra vonatkoztatva vizsgáltuk, amely Bentall-mütét esetén 299 hónap, David-operációkor 116 hónap, míg Yacoub-beavatkozás esetén 42 hónap volt.

\section{Megbeszélés}

Marfan-szindrómában az aortagyök-rekonstrukciós műtétek általában a betegek fiatalabb életkorában válnak szükségessé $[35,36]$. Az adekvát szívsebészeti kezelési

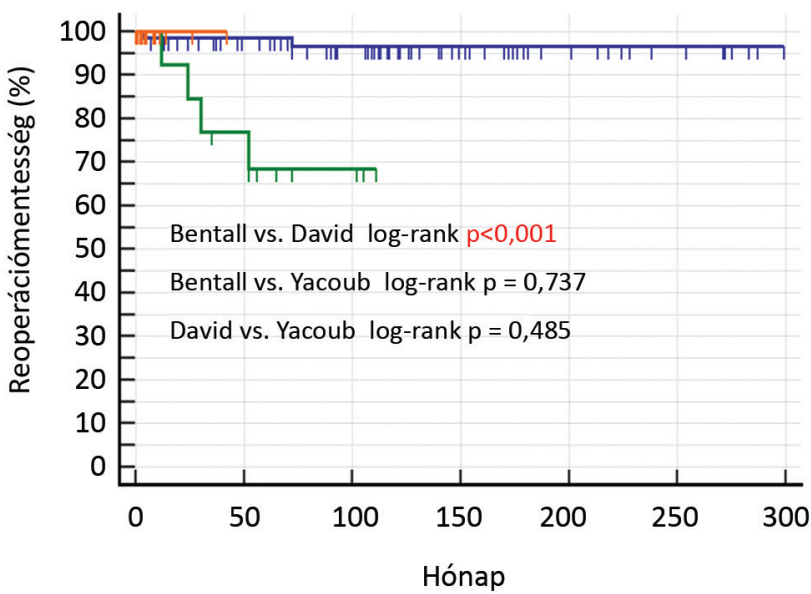

Csoport

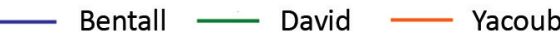

2. ábra

A 3 mútéti típus reoperációtól való mentességének Kaplan-Mei er-görbéje. David-beavatkozás esetén a reoperáció szignifikánsan gyakoribb, mint Bentall-műtétkor. Összehasonlításkor a teljes utánkövetési időszakot vettük figyelembe, amely Bentallmútét esetén 299 hónap, David-operációkor 111 hónap, míg Yacoub-beavatkozás esetén 42 hónap volt

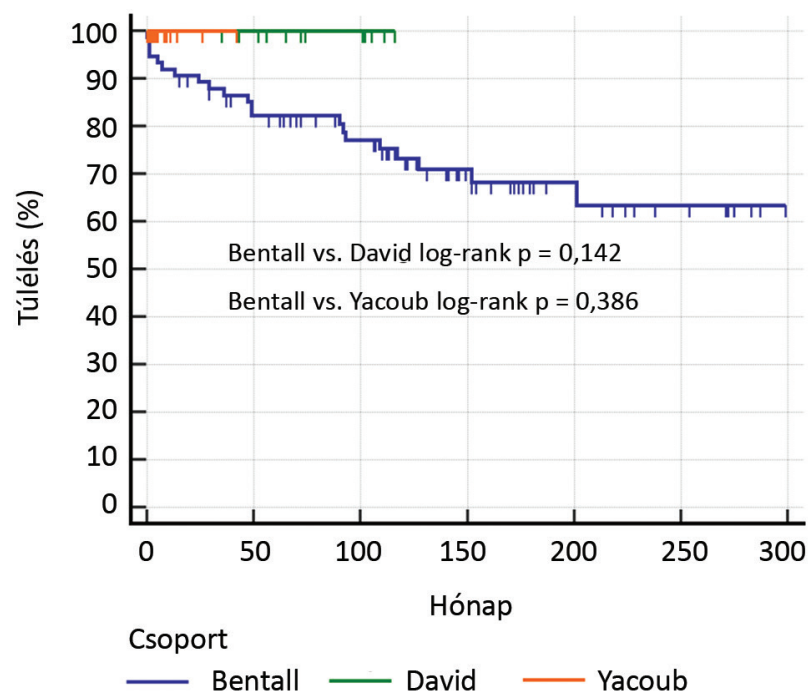

3. ábra

A 3 mútéti típus túlélésének Kaplan-Meier-görbéje. Bentall-mútét esetén a teljes követési időszak idején a túlélés $67,7 \pm 7,9 \%$ nak adódott. Összehasonlításkor a teljes utánkövetési időszakot vettük figyelembe, amely Bentall-mútét esetén 299 hónap, David-operációkor 116 hónap, míg Yacoub-beavatkozás esetén 42 hónap volt

lehetőségek kialakulása előtt a Marfan-szindrómában szenvedő betegek várható élettartama jóval alulmaradt a normálpopulációénak. 1972-ben Murdoch és mtsai vizsgálatában az elhunyt Marfan-szindrómás betegek átlagéletkora mindösszesen 32 év volt; az ismert halálokok 70\%-ának hátterében az aorta dilatatiója és azok komplikációi álltak [37]. Az életet veszélyeztető aortadissectio epidemiológiájának nagyszámú beteganyagon történő vizsgálatakor Marfan-szindrómás betegekben 38, míg a nem beteg populációban 63 éves átlagéletkorban alakult 
ki a dissectio [36]. A dissectio kialakulásának valószínúsége az aorta átmérójével egyenes arányban áll [38], mindezek hangsúlyozzák a betegek követésének és a korai mútéti beavatkozások elvégzésének szükségességét Marfan-szindrómás betegeken. Vizsgálatunkban ennek megfelelően alakult a Marfan-szindrómás betegek mútétkori életkora, amely 29,69 (21,98-41,25) év volt a Bentall-DeBono-csoportban, míg a David I. és a módosított Yacoub-operáción átesők esetén 29,15 $\pm 11,99$ és $35,29 \pm 14,14$ évnek adódott.

A fiatal életkorban elvégzett operáció azt is jelenti, hogy a mútétre kerülő betegek nem rendelkeznek komolyabb mellékbetegségekkel. Számottevő komorbiditásként mindössze magas vérnyomás fordult elő a Bentall-mútétes csoportban (35\%), de ez nem volt szignifikánsan nagyobb, mint a másik két csoport esetén.

A Bentall-mútétre kerülő betegeknél szignifikánsan nagyobb volt az aortaregurgitatio foka, mint a Yacoub-, illetve tendenciózusan nagyobb, mint David-operációk kapcsán. A regurgitatio mértéke nyilvánvalóan összefüggésben áll az aorta átmérőjének méretével. A Bentallcsoportban található, szignifikánsan nagyobb aortaátmérők magyarázata lehet, hogy ezen mútétek között szignifikánsan kisebb arányban fordult elő profilaktikus beavatkozás, mint a David- és Yacoub-operációk esetén.

A gyökrekonstrukciós mútétek kapcsán szövődményként a leggyakrabban ritmuszavarok (posztoperatív pitvarfibrilláció) léptek fel, ezt követte a posztoperatív vérzés. A David-mútéten átesettek több mint felében fordult elő komplikáció az operációt követő első 30 napban, míg a Yacoub-csoportban ez kevesebb beteget érintett.

A késői szövődmények tekintetében nem volt különbség a vizsgált csoportok között.

David-mútét esetén szignifikánsan hosszabbnak bizonyult a CPB és az aortalefogás ideje, következményesen hosszabb mútéti idókkel kellett számolnunk, mint a Bentall-típusnál. Hasonló témában írt közleményben a Bentall- és a David-mútéteket összehasonlító metaanalízis a David-operációk kapcsán hosszabb CPB- és aortalefogási időket talált [35]. Coselli és mtsai 316, Marfan-szindrómás beteg aortagyök-rekonstrukcióját elemezték, és összehasonlították a TRR-t a billentyümegőrző aortagyök-rekonstrukciókkal. Eredményeik alapján a TRR szignifikánsan rövidebb CPB- és aortalefogási idővel járt, ami megfelel a billentyümegőrző mútétek nehezebb technikai kivitelezhetőségének [39]. A mi vizsgálataink során a technikailag komplexebb Yacoub-mútétek CPB- és aortalefogási ideje nem különbözött a Bentall-beavatkozásokétól, amelyek hasonló hosszúságúak volt, mint a már említett metaanalízis [35] esetén, tehát az egyenlő idők nem a Bentall-mútétek elnyújtottsága miatt voltak. Ezen eredményeink mutatják, hogy az összetettebb Yacoub-operáció elvégezhető a mútéti idő megnyúlása nélkül, ezt azonban nem mondhatjuk el a David-beavatkozásról. Ez volt az alapvető oka annak, hogy az elsőként bevezetett, David-féle mútéti technikáról a módosított remodellációs technikára tértünk át, annak könnyebb kivitelezhetősége és reprodukálhatósága miatt. Mint eredményeink is mutatják, a posztoperatív szövődmények tekintetében is kedvezőbb volt a remodellációs mútét.

David-mútét esetén a primer mútét elégtelensége miatt szignifikánsan gyakrabban volt szükség reoperációra, mint Bentall-operáció kapcsán (2. ábra). Marfan-szindrómában a betegség következtében az aortabillentyú struktúrája is károsodhat [40], ami magyarázatul szolgálhat a billentyúmegôrző beavatkozások során megfigyelt nagyobb reoperációs rátára. Benedetto és mtsai metaanalízisükben billentyúmegőrző mútétek esetén négyszeres, aortabillentyưn történő reintervenciós rátát találtak a billentyú cseréjével járó mútétekhez képest. Amikor a reimplantációs technikákat hasonlították össze a Bentallmútétekkel, az előbbiek továbbra is alsóbbrendûnek bizonyultak ebben a tekintetben hosszú távon [21]. Shrestha és mtsai az intézetükben végzett David-mútétek elemzésekor a Marfan-szindrómás populációnál 23\%-os reoperációs arányt találtak 12 év utánkövetés távlatában [41]. Nicolo és mtsai vizsgálata 20 év utánkövetés során szintén kisebb arányú billentyűeredetû beavatkozást regisztrált a Bentall-mútétek esetében [42]. A Bentall-mứtétek esetén azonban Vallabhajosyula és mtsai magasabb posztoperatív vérzési rátát és magasabb permanens pacemaker-beültetési igényt talált a David-mútétekhez képest [27]. Price és mtsai (David-munkacsoport) 10 éves utánkövetés adatait elemezve kimutatták, hogy a Bentall-mútétek esetén a múbillentyú okozta szövődmények jóval gyakoribbak, mint a David-mútét esetében (23\% vs. $4 \%)$ [24]. Flynn és mtsai egy metaanalízis adatait elemezve publikálták, hogy aortagyök-rekonstrukciónál billentyúmegtartás esetében szignifikánsan alacsonyabb az endocarditis és a thromboemboliás szövődmények aránya a Bentall-mútétekhez képest [26].

Módosított Yacoub-mútétek esetén a másik két csoporthoz képest nem találtunk különbséget a reintervenció tekintetében, azonban messzemenő következtetések levonásához hosszabb követési időre van szükség. Schäfers és mtsai 2017-ben közölték eredményeiket a Marfan-szindrómás betegeken (67 beteg) végzett módosított Yacoub-mútéttel, melyben megállapították, hogy ezen mútét segítségével 10 éves utánkövetés során csak a betegek $15 \%$-ában volt szükség ismételt beavatkozásra [25]. Vizsgálatunkban a túlélés tekintetében nem mutatkozott különbség a három mútéti típus között. A teljes utánkövetési idő (lásd feljebb) alatt a hosszú távú túlélés 67,7 \pm 7,9\%-nak bizonyult Bentall-mútét esetén, míg 100\% volt David- és Yacoub-operációk kapcsán (3. ábra). Az utóbbiaknál azonban jelentősen rövidebb követési idők álltak rendelkezésre. A Bentall-csoport hosszú távú túlélésével kapcsolatban fontos hangsúlyozni, hogy a mútétek mindössze 39\%-a volt profilaktikus.

Vizsgálatunk korlátja, hogy az utánkövetési idók nem azonosak a csoportok között. Ennek ellenére értékes kö- 
vetkeztetések vonhatók le a 3 mütéti típus összehasonlításakor. David- és Yacoub-mütéteknél az elemszám alacsony, illetve a Yacoub-csoportban az utánkövetési idő nem kellően hosszú, hogy a reoperációról és a hosszú távú túlélésről megfelelő képet kapjunk.

\section{Következtetés}

Eredményeink azt mutatják, hogy az arany standard mütétnek számító Bentall-mútét a nemzetközi adatoknak megfelelően jó hosszú távú eredménnyel reprodukálható a Marfan-szindrómás populációban. Napjainkban adott betegcsoportokban a billentyưmegtartó mütétek válnak hangsúlyossá, tekintettel a ritkább késői szövődményekre és a betegek életminőségére. Klinikánkon a billentyümegtartó gyökrekonstrukciós mútétek között a rövidebb CPB- és aortalefogási idők következtében a módosított Yacoub-mütét kedvezőbbnek adódik, mint a David I. mütét. Mind a nemzetközi, mind a saját adataink alapján a billentyưmegtartó gyökrekonstrukciós mútéti típusok is sikerrel végezhetők a Marfan-szindrómás betegek esetében. Ám a fentebb említett limitációknak megfelelően hosszabb távú betegkövetésre van szükség, hogy a 3 csoport reoperációs rátáját és hosszú távú túlélését pontosan meghatározhassuk. Mindazonáltal Marfan-szindrómás betegeink szisztematikus és rendszeres követésével és a profilaktikus beavatkozás elvégzésével jelentősen csökkenthető a betegek korai érkatasztrófák által okozott mortalitása.

Anyagi támogatás: A kutatást az Innovációs és Technológiai Minisztérium Felsőoktatási Intézményi Kiválósági Programja finanszírozta, a Semmelweis Egyetem Terápiás Fejlesztés tématerületi programja keretében. A jelen tanulmány megjelenését a Nemzeti Kutatási, Fejlesztési és Innovációs Hivatal támogatta (NKFIA; NVKP_16-12016-0017 Nemzeti Szívprogram).

Szerzői munkamegosztás: P. M., S. R., B. K.: Adatgyưjtés, az adatok kiértékelése, statisztikai elemzés, a kézirat elkészítésében való részvétel. S. C.-M., Á. B., K. Á.: Adatgyüjtés, a kézirat elkészítésében való részvétel. H. I., Sz. A., N. E., K. A., B. E., M. B., Sz. Z.: A kézirat ellenőrzése, szakmai tanácsadás. A cikk végleges változatát valamennyi szerző elolvasta és jóváhagyta.

Érdekeltségek: A szerzőknek nincsenek érdekeltségeik.

\section{Köszönetnyilvánítás}

Köszönetünket fejezzük ki a Marfan-szindrómások közösségének és beteg-érdekvédelmi munkatársunknak, Varró Csillának a munkánk során nyújtott támogatásukért.

\section{Irodalom}

[1] Dietz H. Marfan syndrome. In: Adam MP, Ardinger HH, Pagon RA, et al. (eds.) GeneReviews ${ }^{\circledR}$ [Internet]. University of Washington, Seattle, WA, 1993; pp. 1-22. [Updated: Oct 12, 2017]

[2] Szabolcs Z, Nagy G, Bartha E, et al. Total proximal reconstruction of chronic aortic dissection in patients with Marfan syndrome. [Marfan-kóros betegeken észlelt krónikus aorta dissectio teljes proximális korrekciója.] Orv Hetil. 1997; 138: 681-685. [Hungarian]

[3] Fazekas A. Marfan syndrome and aortic aneurysm. Letters to the Editor. [A Marfan-syndroma és az aorta aneurysmája. Levelek a Szerkesztőhöz.] Orv Hetil. 1972; 113: 2381. [Hungarian]

[4] Szabolcs Z, Hüttl T, Szudi L, et al. Aortic root reconstruction in a nine-year-old child: a case report. J Hear Valve Dis. 2009; 18: $220-222$

[5] Judge DP, Dietz HC. Marfan's syndrome. Lancet 2005; 366 : 1965-1976.

[6] Ágg B, Benke K, Szilveszter B, et al. Possible extracardiac predictors of aortic dissection in Marfan syndrome. BMC Cardiovasc Disord. 2014; 14: 47.

[7] Benke K, Ágg B, Mátyás G, et al. Gene polymorphisms as risk factors for predicting the cardiovascular manifestations in Marfan syndrome: role of folic acid metabolism enzyme gene polymorphisms in Marfan syndrome. Thromb Haemost. 2015; 114: $748-756$.

[8] Ágg B, Szilveszter B, Daradics N, et al. Increased visceral arterial tortuosity in Marfan syndrome. Orphanet J Rare Dis. 2020; 15: 91.

[9] Robinson PN, Arteaga-Solis E, Baldock C, et al. The molecular genetics of Marfan syndrome and related disorders. J Med Genet. 2006; 43: 769-787.

[10] Benke K, Ágg B, Meienberg J, et al. Hungarian Marfan family with large FBN1 deletion calls attention to copy number variation detection in the current NGS era. J Thorac Dis. 2018; 10: 2456-2460.

[11] Benke K, Ágg B, Szilveszter B, et al. The role of transforming growth factor-beta in Marfan syndrome. Cardiol J. 2013; 20: 227-234.

[12] Loeys BL, Dietz HC, Braverman AC, et al. The revised Ghent nosology for the Marfan syndrome. J Med Genet. 2010; 47: 476-485.

[13] LeMaire SA, Russell L. Epidemiology of thoracic aortic dissection. Nat Rev Cardiol. 2011; 8: 103-113.

[14] Ades L. Guidelines for the diagnosis and management of Marfan syndrome. Hear Lung Circ. 2007; 16: 28-30.

[15] Baumgartner H, Falk V, Bax JJ, et al. 2017 ESC/EACTS Guidelines for the management of valvular heart disease. Eur Heart J. 2017; 38: 2739-2791.

[16] Hiratzka LF, Bakris GL, Beckman JA, et al. 2010 ACCF/AHA/ AATS/ACR/ASA/SCA/SCAI/SIR/STS/SVM guidelines for the diagnosis and management of patients with thoracic aortic disease. Circulation 2010; 121: e266-e369. [Erratum: Circulation 2010; 122(4): e410.]

[17] Bentall H, De Bono A. A technique for complete replacement of the ascending aorta. Thorax 1968; 23: 338-339.

[18] Aomi S, Nakajima M, Nonoyama M, et al. Aortic root replacement using composite valve graft in patients with aortic valve disease and aneurysm of the ascending aorta: twenty years' experience of late results. Artif Organs 2002; 26: 467-473.

[19] Benke K, Ágg B, Szabó L, et al. Bentall procedure: quarter century of clinical experiences of a single surgeon. J Cardiothorac Surg. 2016; 11: 19. 
[20] Mookhoek A, Korteland NM, Arabkhani B, et al. Bentall procedure: a systematic review and meta-analysis. Ann Thorac Surg. 2016; 101: 1684-1689.

[21] Benedetto U, Melina G, Takkenberg JJ, et al. Surgical management of aortic root disease in Marfan syndrome: a systematic review and meta-analysis. Heart 2011; 97: 955-958.

[22] David TE. The aortic valve-sparing operation. J Thorac Cardiovasc Surg. 2011; 141: 613-615.

[23] Yacoub MH, Gehle P, Chandrasekaran V, et al. Late results of a valve-preserving operation in patients with aneurysms of the ascending aorta and root. J Thorac Cardiovasc Surg. 1998; 115: 1080-1090.

[24] Price J, Magruder JT, Young A, et al. Long-term outcomes of aortic root operations for Marfan syndrome: a comparison of Bentall versus aortic valve-sparing procedures. J Thorac Cardiovasc Surg. 2016; 151: 330-338.

[25] Schneider U, Ehrlich T, Karliova I, et al. Valve-sparing aortic root replacement in patients with Marfan syndrome - the Homburg experience. Ann Cardiothorac Surg. 2017; 6: 697-703.

[26] Flynn CD, Tian DH, Wilson-Smith A, et al. Systematic review and meta-analysis of surgical outcomes in Marfan patients undergoing aortic root surgery by composite-valve graft or valve sparing root replacement. Ann Cardiothorac Surg. 2017; 6: 570581.

[27] Vallabhajosyula P, Szeto WY, Habertheuer A, et al. Bicuspid aortic insufficiency with aortic root aneurysm: root reimplantation versus Bentall root replacement. Ann Thorac Surg. 2016; 102: $1221-1228$

[28] Cameron DE, Alejo DE, Patel ND, et al. Aortic root replacement in 372 Marfan patients: evolution of operative repair over 30 years. Ann Thorac Surg. 2009; 87: 1344-1350.

[29] David TE, David CM, Ouzounian M, et al. A progress report on reimplantation of the aortic valve. J Thorac Cardiovasc Surg. 2020; 161: 890-899.el.

[30] Martens A, Beckmann E, Kaufeld T, et al. Valve-sparing aortic root replacement (David I procedure) in Marfan disease: singlecentre 20-year experience in more than 100 patients. Eur J Cardiothorac Surg. 2019; 55: 476-483.

[31] Pólos M, Benke K, Ágg B, et al. Psychological factors affecting Marfan syndrome patients with or without cardiac surgery. Ann Palliat Med. 2020; 9: 3007-3017.
[32] Benke K, Ágg B, Pólos M, et al. The effects of acute and elective cardiac surgery on the anxiety traits of patients with Marfan syndrome. BMC Psychiatry 2017; 17: 253

[33] Kunihara T, Arimura S, Sata F, et al. Aortic annulus does not dilate over time after aortic root remodeling with or without annuloplasty. J Thorac Cardiovasc Surg. 2018; 155: 885-894.e3.

[34] Ágota A, Ágg B, Benke K, et al. The establishment of the Marfan syndrome biobank in Hungary. [Marfan-szindróma biobankjának létrehozása.] Orv Hetil. 2012; 153: 296-302. [Hungarian]

[35] Burgstaller JM, Held U, Mosbahi S, et al. A systemic review and meta-analysis: long-term results of the Bentall persus the David procedure in patients with Marfan syndrome. Eur J Cardiothorac Surg. 2018; 54: 411-419.

[36] de Beaufort HW, Trimarchi S, Korach A, et al. Aortic dissection in patients with Marfan syndrome based on the IRAD data. Ann Cardiothorac Surg. 2017; 6: 633-641.

[37] Murdoch JL, Walker BA, Halpern BL, et al. Life expectancy and causes of death in the Marfan syndrome. N Engl J Med. 1972; 286: 804-808.

[38] Saeyeldin A, Zafar MA, Velasquez CA, et al. Natural history of aortic root aneurysms in Marfan syndrome. Ann Cardiothorac Surg. 2017; 6: 625-632.

[39] Coselli JS, Volguina IV, LeMaire SA, et al. Early and 1-year outcomes of aortic root surgery in patients with Marfan syndrome: a prospective, multicenter, comparative study. J Thorac Cardiovasc Surg. 2014; 147: 1758-1767.e4.

[40] Fleischer KJ, Nousari HC, Anhalt GJ, et al. Immunohistochemical abnormalities of fibrillin in cardiovascular tissues in Marfan's syndrome. Ann Thorac Surg. 1997; 63: 1012-1017.

[41] Shrestha M, Baraki H, Maeding I, et al. Long-term results after aortic valve-sparing operation (David I). Eur J Cardiothorac Surg. 2012; 41: 56-61.

[42] Nicolo F, Romeo F, Lio A, et al. Long-term results of aortic root surgery in Marfan syndrome patients: a single-center experience. J Heart Valve Dis. 2017; 26: 397-404.

(Pólos Miklós dr., Budapest, Városmajor u. 68., 1122 e-mail: miklospolos@gmail.com)

\section{"Numquam periclum sine periclo vincitur." (Veszélyt nem győzhetsz le veszélytelen.)}

A cikk a Creative Commons Attribution 4.0 International License (https://creativecommons.org/licenses/by/4.0/) feltételei szerint publikált Open Access közlemény, melynek szellemében a cikk bármilyen médiumban szabadon felhasználható, megosztható és újraközölhetö, feltéve, hogy az eredeti szerző és a közlés helye, illetve a CC License linkje és az esetlegesen végrehajtott módositások feltüntetésre kerülnek. (SID_1) 